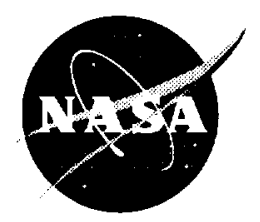

\title{
Electrolysis Propulsion for Spacecraft Applications
}

Wim A. de Groot and Lynn A. Arrington

NYMA, Inc., Brook Park, Ohio

James F. McElroy

Hamilton Standard, Windsor Locks, Connecticut

Fred Mitlitsky, Andrew H. Weisberg,

Preston H. Carter II, and Blake Myers

Lawrence Livermore National Laboratory, Livermore, California

Brian D. Reed

Lewis Research Center, Cleveland, Ohio

National Aeronautics and

Space Administration

Lewis Research Center 
Available from

NASA Center for Aerospace Information 800 Elkridge Landing Road

Lynthicum, MD 21090-2934

Price Code: A03

National Technical Information Service 5287 Port Royal Road Springfield, VA 22100 Price Code: $\mathrm{A03}$ 


\title{
Electrolysis Propulsion for Spacecraft Applications
}

\author{
Wim A. de Groot ${ }^{*}$ and Lynn A. Arrington ${ }^{* *}$ \\ NYMA Inc, NASA LeRC Group \\ Brook Park, Ohio \\ James F. McElroy ${ }^{* * *}$ \\ Hamilton Standard \\ Windsor Locks, Connecticut
}

Fred Mitlitsky ${ }^{\dagger}$, Andrew H. Weisberg ${ }^{\dagger \dagger}$, Preston H. Carter $\Pi^{\ddagger}$, and Blake Myers
Lawrence Livermore National Laboratory
Livermore, California
Brian D. Reed
NASA Lewis Research Center
Cleveland, Ohio

\begin{abstract}
Electrolysis propulsion has been recognized over the last several decades as a viable option to meet many satellite and spacecraft propulsion requirements. This technology, however, was never used for in-space missions. In the same time frame, water based fuel cells have flown in a number of missions. These systems have many components similar to electrolysis propulsion systems. Recent advances in component technology include: lightweight tankage, water vapor feed electrolysis, fuel cell technology, and thrust chamber materials for propulsion. Taken together, these developments make propulsion and/or power using electrolysis/fuel cell technology very attractive as separate or integrated systems. A water electrolysis propulsion testbed was constructed and tested in a joint NASA/Hamilton Standard/Lawrence Livermore National Laboratories program to demonstrate these technology developments for propulsion. The results from these testbed experiments using a $1-\mathrm{N}$ thruster are presented. A concept to integrate a propulsion system and a fuel cell system into a unitized spacecraft propulsion and power system is outlined.
\end{abstract}

\footnotetext{
- Sr. Research Engineer, Senior Member AIAA

* Research Engineer, Member AIAA

** Program Manager

$\dagger$ Program Manager, Member AlAA

${ }^{+\dagger}$ Space Group Scientist, Member AIAA

‡ Aerospace Engineer, Member AIAA

$\ddagger$ Mechanical Engineer, Associate Fellow AlAA
}

\section{Introduction}

Innovative new systems are being sought to improve mission performance and reduce cost. Electrolysis propulsion, either alone or combined with fuel cell power offers the potential to provide a synergistic power and propulsion system for small spacecraft.

On-board propulsion systems must satisfy a variety of propulsion functions, including orbit insertion, attitude control, station keeping, repositioning, and primary propulsion for planetary spacecraft. There already exists a number of low thrust propulsion options to carry out these maneuvers. Cold gas propulsion is commonly used when propulsion requirements are small and where cost and system simplicity are decisive factors. Monopropellant hydrazine $\left(\mathrm{N}_{2} \mathrm{H}_{4}\right)$ systems are generally used for orbit insertion of smaller satellites because of its higher specific impulse (Isp) compared to cold gas systems. However, monopropellant systems are more costly and complex than cold gas. Storable bipropellants, utilizing nitrogen tetroxide (NTO) as oxidizer and either monomethylhydrazine (MMH) or $\mathrm{N}_{2} \mathrm{H}_{4}$ as fuel, 
have been used extensively for orbit insertion of medium to large satellites and for primary propulsion in planetary spacecraft. These systems in turn are more costly and complex than monopropellant systems.

A recent trend is toward the use of electric thruster systems for satellite on-orbit functions. For example, arcjets are already used for NorthSouth station keeping of geostationary satellites. ${ }^{1}$ High power ion and Hall thrusters are being developed for orbit transfer and primary planetary propulsion missions. ${ }^{2}$ Pulsed plasma thrusters are poised to be flight tested for precision on-orbit functions on smaller satellites.

Water electrolysis propulsion can provide higher performance than the established chemical propulsion options. At equal thrust levels, power requirements of water electrolysis propulsion $(\sim 0.17 \mathrm{~N} / \mathrm{kW})$ are greatly below those of electric propulsion devices $(\sim 0.08 \mathrm{~N} / \mathrm{kW}$ for $2.2 \mathrm{~kW}$ arcjets, and $0.03 \mathrm{~N} / \mathrm{kW}$ for $2.6 \mathrm{~kW}$ ion thrusters). These advantages become more pronounced at lower power levels, where efficiencies of electric propulsion devices are significantly reduced. In a water electrolysis propulsion system, water stored in a lightweight, low pressure tank is fed to an electrolyzer. The electrolyzer consumes electrical energy to decompose the water into pressurized hydrogen and oxygen. If solar energy is available, these devices can also serve as a load leveling function, storing the energy as hydrogen and oxygen gases. The propellant is clean and inexpensive, reducing costs associated with propellant acquisition, ground handling, maintenance, and launch. Water can be stored in compact, lightweight tanks at relatively high density $(1.0 \mathrm{~g} / \mathrm{cc})$. Storage requirements for propulsion are set by one or more high impulse "burns", where the hydrogen and oxygen are stored in separate tanks, to be mixed and ignited inside the combustion chamber of a conventional rocket engine. The gaseous hydrogen/gaseous oxygen $\left(\mathrm{GH}_{2} / \mathrm{GO}_{2}\right)$ propellants have performance measured at an Isp of over $350 \mathrm{~s}$ (at thrust levels of 0.5 to $15 \mathrm{~N}){ }^{3}$ which is superior to earth storable chemical alternatives. The products of combustion are clean and free of carbon, sparing optics and other sensitive instruments from degradation. Contamination issues with water vapor condensation are mission dependent and need to be investigated.

Neither mechanical pumps nor pressurant gas are required to feed a water electrolysis rocket system, because electrolyzers are now able to electrochemically "pump" water decomposition products from ambient pressure up to pressures of at least $20 \mathrm{MPa}$. The absence of a pressurization system simplifies the propellant feed significantly and eliminates components that must have long-term compatibility with propellants. For deep space missions, water is significantly easier to contain than the hypergolic Earth storables, offering stability over a relatively wide temperature range. A final advantage of the water rocket is its dual mode potential. For relatively high thrust applications, the system can be used as a bipropellant engine. For low thrust levels and/or small impulse bit requirements, cold gas oxygen can be used alone.

The potential of the water electrolysis rocket as a high performance propulsion device has been recognized for some time. Newman ${ }^{4}$ discussed water electrolysis propulsion for reaction control systems (RCS) in 1965. Stechman et al. ${ }^{5}$ demonstrated that $500,000 \mathrm{~N}-\mathrm{s}$ of total impulse could be obtained with a water electrolysis satellite propulsion system during laboratory tests with $20 \mathrm{~N}$ and $0.5 \mathrm{~N}$ engines. Such a propulsion system, however, was never accepted for a flight program. This was partly due to the decision that the improved performance was not sufficient to mitigate the perceived increase in complexity. Other disadvantages included: the large tankage needed for gaseous storage, the increased weight due to the need to pressure feed the electrolyzer, the limited power available for propellant generation, the propellant utilization penalty of gas dryers, and the ignition requirement.

Recent advances in propellant storage technology, ${ }^{6}$ water vapor feed electrolysis, ${ }^{7,8}$ and solar array performance, along with a flurry of research in $\mathrm{GH}_{2} / \mathrm{GO}_{2}$ ignition (e.g. the LEAP program and SSTO, ${ }^{9}$ among others) have made the use of electrolysis propulsion more attractive from a mass standpoint. In addition, there now exists an innovative new system which improves the performance of small spacecraft called the Unitized Regenerative Fuel Cell (URFC), an integrated electrolyzer and fuel cell in a single reversible unit. ${ }^{7}$ This system offers the potential for dual use (power and propulsion) and a substantial weight savings over established, separate, propulsion and power systems in certain mission scenarios. A Hamilton Standard study $^{8}$ showed that for low-earth-orbit (LEO) satellites, the specific energy (energy capacity per weight of storage unit) of a water fuel cell was better than state-of-the art $\mathrm{NiCad}$ batteries and approximately equal to that of $\mathrm{NiH}$ batteries, about $15 \mathrm{~W}-\mathrm{hr} / \mathrm{kg}$. This study did not include the 
lightweight tankage proposed in the current system, which would provide higher specific energy. Integrating the fuel cell system with an electrolysis propulsion system further reduces the combined propulsion and power system weight due to common components, such as gas storage and the electrolyzer/fuel cell. The energy density of such a unitized system for LEO applications increases an order of magnitude $(\sim 150 \mathrm{~W}-\mathrm{hr} / \mathrm{kg})$. Also, the weight advantage of both stand alone fuel cells and unitized systems increases for missions with a longer energy charge-discharge cycles. This results from the separation of power and energy inside the URFC. Batteries scale linearly with energy storage requirement, whereas for URFC's, only the storage tanks scale with energy storage requirements. The reactor stack is scaled only for power.

Perceived system complexity can be a major obstacle to in-flight use. The addition of an electrolyzer to the propulsion system slightly increases complexity over a gas pressurized system. However, the combination of a tenfold or more reduction in combined propulsion/power system mass over state-of-the-art systems and the cleanness of propellants can favor a more complex system.

The full advantage of electrolysis propulsion is gained when possible synergies with other subsystems are realized. A schematic of such a proposed unitized system is shown in Fig. 1. Because most of the power for flight electronics isn't required during orbital transfer maneuvers, it will often be available to electrolyze water without adding additional capability and mass penalty. High performance gas storage tanks can provide some, if not most of the structure required by spacecraft that must function as stiff instrument platforms. A unitized propulsion and power system was proposed for a New Millennium Program spacecraft concept. ${ }^{7}$ For the system proposed, a URFC was used to replace the baseline batteries for energy storage. The modest $30 \%$ increase in electrolyzer mass was more than offset by the savings in battery mass which accounted for as much as $10 \%$ of the wet mass. The projected benefits of such an integrated system were a weight savings of over $50 \%$ for low-earth-orbit spacecraft, increasing with higher energy storage needs. Missions analyses show that electrolysis systems also provide significant weight savings for applications which require a large number of impulsive burns.
This paper will first describe recent advances in component technologies which may make electrolysis propulsion a viable candidate for a variety of mission scenarios. This is followed by a description of a testbed built at NASA LeRC in a cooperative program partnering Lewis Research Center, Hamilton Standard and Lawrence Livermore National Laboratories, and results obtained from experiments in a high altitude simulation chamber.

\section{Component Technologies}

A schematic of a water electrolysis propulsion system which could be used to provide all propulsion functions in a small satellite application is shown in Fig. 2. It includes a primary thruster for high $\Delta \mathrm{V}$ maneuvers, four cold gas thrusters for thrust vector control during primary burns, and twelve cold gas thrusters for attitude control (ACS). This system is designed to replace two conventional (i.e. cold gas and $\mathrm{N}_{2} \mathrm{H}_{4}$ ) systems that would be needed to perform the same functions in a mission utilizing state-ofthe-art technology. Key components of the water electrolysis system are discussed below. They are the electrolyzer, gas dryers, the water and propellant tankage, the propellant feed system, and the thrusters. In addition, the technology to integrate propulsion and power is discussed.

\section{Electrolyzer}

A detailed description of the water vapor feed electrolyzer is given in Reference 7. This electrolyzer is based on Hamilton Standards' solid polymer electrolyte (SPE $\left.{ }^{\oplus}\right)$ technology. The electrolyzer uses this sulfonic acid proton exchange membrane as the sole electrolyte. The membrane is fashioned into electrochemical cells by bonding catalyst electrodes to both faces. The single electrolysis cell consists of a water feed chamber, a water permeable membrane, a hydrogen chamber, a SPE membrane, an oxygen chamber, an electrochemical hydrogen pump, and electrical insulators on both end plates. Hydrogen and oxygen are produced on either side of the SPE membrane with the application of DC power. The water feed chamber is separated from the hydrogen gas chamber by water permeable membranes which allow osmotic water transport into the hydrogen chamber. Because water is being consumed to produce propellants, a water gradient is established across the water feed barrier and more water from the storage tank enters the cell. An electrochemical 
hydrogen pump, drawing a few milliwatt assures that no hydrogen builds up in the water feed chamber.

The reliability of the water vapor feed electrolysis system has been demonstrated previously in an accelerated test simulating 10 years worth of propellant production for North South station keeping (NSSK) on a geosynchronous satellite. ${ }^{10}$ Utilizing the electrochemical "pumping" action of the SPE electrolyzer, gaseous hydrogen and oxygen up to pressures of $2.72 \mathrm{MPa}(20 \mathrm{MPa}$ has been demonstrated) were produced, with subsequent burns consuming propellants down to $0.7 \mathrm{MPa}$ tank pressure. SPE-based fuel cells have flown on seven Gemini missions," but SPE-based vapor feed electrolyzers have not been flight qualified yet. Sizing of the electrolyzer for selected missions depends on the systems design approach. Either the electrolyzer is scaled according to the available power and the mission is accomplished with the given propellant generation rate, or the electrolyzer is scaled according to the mission requirements which dictate the required propellant generation rate and therefore power. In this case, additional solar collectors to drive the electrolyzer are added. On high delta-V missions, the higher Isp of the hydrogen/oxygen propellants compensates for the additional mass of components (e.g., electrolyzers, gas tanks, additional solar collectors) that state-of-the-art chemical propulsion systems do not require.

\section{Gas Dryers}

Both the hydrogen and the oxygen leaving the electrolysis unit contain small quantities of water vapor. If not removed, this water vapor could condense inside the tanks and propellant lines. Furthermore, the presence of water vapor inside the propellants will reduce thruster performance. The installation of propellant dryers based on a desiccant bed is a simple solution. This would be a highly reliable passive component. For small spacecraft applications, the amount of water vapor will be low, so this component will be small with relatively low weight. The amount of water vapor depends on gas pressure. A conservative estimate is that for a $7.0 \mathrm{MPa}$ system, approximately $2 \%$ need to be added to the propellant mass in order to account for the desiccant mass. The amount of water absorbed in the desiccant under these conditions is approximately $0.25 \%$ of the total water wet mass.

\section{Propellant Feed System}

The propellant feed system described here is designed for maximum simplicity. Pressurization of the propellants is accomplished through the electrolyzer. Direct feed lines from the electrolyzer to the tanks supply propellants. For highly controllable impulse bits and maximum combustion efficiency, regulators are needed between the tanks and thruster to control the propellant mass flow rates. For less restrictive needs, a blowdown system could be used to simplify the operation and reduce system weight resulting in some performance reduction.

Over the last several years, strict micropropulsion requirements have driven the development in valve and regulator technologies. This has resulted in the reduction of leak rates (internal leakage $<10^{-6} \mathrm{scc} / \mathrm{h}$ He for valves and $<1 \mathrm{scc} / \mathrm{h}$ for regulators, respectively), minimizing power requirements (< 9 Watts), and minimizing mass (10-100 gms). ${ }^{12}$ In order to satisfy even stricter requirements, near term developments are focused on microelectromechanical systems (MEMS) technology to further reduce the mass and achievable flow rates. The biggest obstacle with MEMS, however, is the leak rate, which has been greater than for conventionally manufactured valves, and the need to filter even the smallest particles.

\section{Water and Propellant Tankage}

Because the vapor feed electrolyzer pressurizes the propellant, the water supply can be stored at ambient pressures in thin-walled, light weight tanks. The storage of gaseous reactants, especially hydrogen, however, has always been a problem for on orbit applications. For missions in which a velocity change must be accomplished in a single, large $\Delta \mathrm{V}$ burn, the required tank mass to contain the required gaseous hydrogen is high.

If multiple burns are possible to accomplish the mission, filling and draining gas storage pressure vessels multiple times can effectively reduce the mass penalty of gaseous hydrogen storage. The propellant tanks are now sized to accommodate only the largest burn of the mission, the required mass is effectively "amortized" over the number of times that the tank gets refilled during the mission.

The figure of merit for lightweight pressure tanks is the performance factor, which is the burst pressure multiplied by the internal volume and divided by the tank weight $\left(P_{b} . V / W\right)$. Recent 
work on propellant tankage ${ }^{6.8}$ has greatly improved the performance factor. State of the art performance factors are 4 million-cm for large tanks (lower for smaller tanks), with a safety factor (maximum expected operating pressure / burst pressure) of 1.5. Because tanks are generally assumed to be pressurized in flight, this safety factor is conservative for tanks that are not pressurized when humans, launch vehicles, or other spacecraft are at risk. The performance factor is aggressive compared to commercially available space qualified pressure vessels which have a performance factor of 2 million $-\mathrm{cm}$. However, aggressive performance factors are feasible using thin bladder-liners overwrapped with T1000 carbon fiber composite. Prototype bladder-lined tanks of modest size have recently been fabricated which achieved 4 million-cm using thick end domes and two heavy stainless steel bosses sized for automotive applications. ${ }^{6}$ Reducing the mass of the bosses and end domes should enable 5 million-cm tanks for large volumes and 4 million-cm tanks for modest volumes. Small tank volumes (which generally result in low performance factors) are readily contained within required structural members. Thus, aggressive performance factors are justified even for small volumes, if only the mass increment of turning structural members into pressure vessels is considered as tank weight. This results in a significant weight reduction as compared to the use of conventional tankage.

\section{Thrusters}

For the current study, a $1-\mathrm{N} \mathrm{GH} / \mathrm{GO}_{2}$ thruster was build into the testbed. This thruster consisted of an ignitor, an injector, a chamber, a throat, and a 23.3:1 area ratio nozzle. Small $\mathrm{GH}_{2} / \mathrm{GO}_{2}$ thrusters have been developed and tested over the last three decades. ${ }^{13}$ Flight type thrusters built for satellite electrolysis propulsion concepts (thrust levels from 0.5 to $22 \mathrm{~N}$ ) have been tested extensively. ${ }^{4,5,14}$ A $22-\mathrm{N}$ thruster demonstrated over 69,000 firings with a total of 4 hours burn time without noticeable degradation, achieving an Isp of $355 \mathrm{~s}$. In the same program, a $0.5-\mathrm{N}$ thruster demonstrated over 150,000 firings and 10 hours total burn time, with a performance of 331 s. These tests showed that for these small thrusters, optimal ignition was achieved at higher chamber pressures $(>160 \mathrm{kPa}$ ), driving optimal designs to operate at higher tank and electrolysis pressures.

Thrusters built for potential application as the space station propulsion system (thrust levels from 110 to $220 \mathrm{~N}$ ) have also been tested extensively. ${ }^{15.16}$ These non-optimized thrusters have achieved Isp's up to $360 \mathrm{~s}$ at stochiometric mixture ratio. Most recently, 2200-N, $\mathrm{GH}_{2} / \mathrm{GO}_{2}$ thrusters were developed for the $X-33$, the technology demonstrator vehicle for the Reusable Launch Vehicle.

In all of the past work, fuel-film cooling was used for thermal and oxidation protection of thruster walls. The presence of such a fuel-film reduced thruster performance. In order to maximize thruster performance in the highly oxidizing combustion environment of a stochiometric $\mathrm{GH}_{2} / \mathrm{GO}_{2}$ thruster, advanced thruster materials, such as iridium-coated rhenium (Ir/Re) may be needed. This material provides a $700 \mathrm{~K}$ increase in operating temperature over the best state-of-the-art chamber material. Ir/Re rockets have allowed the virtual elimination of fuel-film cooling for storable bipropellants, resulting in greatly improved performance. ${ }^{17}$ As the result of an intensive development program, these thrusters are close to being commercially available. For stochiometric $\mathrm{GH}_{2} / \mathrm{GO}_{2}$, Ir/Re with an additional oxide coating for increased oxidation-resistance may be a better option. Several $22-N$, oxidecoated Ir/Re thrusters have been tested on $\mathrm{GH}_{2} / \mathrm{GO}_{2}$ up to a mixture ratio of 17 . $^{18}$

Leveraging the results of advanced thruster materials research and redesigning thrusters to operate with radiative cooling alone, can increase specific impulse by a significant margin (projected Isp > 380 s) while at the same time operating in an oxidizing environment. The additional performance that could be obtained from $\mathrm{GH}_{2} / \mathrm{GO}_{2}$ systems is higher than from storable propellant systems using the same materials.

One major difference between $\mathrm{GH}_{2} / \mathrm{GO}_{2}$ and established chemical thrusters is the need for an ignition source. Incorporation of an ignition source may increase complexity or power requirements and may not meet the stringent pulsing requirements of some low thrust rockets. Spark ignition has been used extensively in previous $\mathrm{GH}_{2} / \mathrm{GO}_{2}$ thruster programs and is the baseline for the $\mathrm{X}-33$ thruster. Alternative ignition sources, including laser, resonance, and catalytic ignition have also been investigated for $\mathrm{GH}_{2} / \mathrm{GO}_{2}{ }^{19}$ Ignition systems are being investigated under technology programs for upgrade of the Shuttle Orbiter RCS and manned lunar/Mars spacecraft, both of which will probably use oxygen/hydrocarbon propellants. 
Integrated Propulsion and Power

Missions amenable to electrolysis propulsion can gain from having both the electrolyzer and the batteries replaced with a URFC. ${ }^{7}$ In this case, the weight of the unitized system is shared by the power and propulsion system thus providing a savings over conventional systems. Recent results have demonstrated that URFCs are capable of many energy storage cycles without significant degradation. ${ }^{6}$ Results from recent accelerated cycle testing are shown in Fig. 3 along with a description of the single cell URFC cycle test conditions. More than 2010 alternate cycles of fuel cell (FC) and electrolyzer (EC) operation were accomplished at four different power levels. Critical system parameters did not change over the course of the test, indicating that life and also the system operated over a wide range.

These results indicate that URFCs should be able to power satellites through many thousands of eclipse periods. Unlike battery power systems which require shallow depth of discharge to achieve long cycle life, URFC energy storage systems should be capable of deep discharges throughout their entire service life.

Table I gives a summary of the status of the different technologies. All technologies have demonstrated performance at NASA's technology readiness level 4 or higher.

\section{Electrolysis Propulsion Breadboard Tests}

As a proof of concept, a complete electrolysis propulsion system was assembled. A schematic of the electrolysis breadboard system is shown in Fig. 4. For simplicity, power was obtained from a $35 \mathrm{~V}$ power supply, to simulate the small spacecraft bus. The maximum available power was $700 \mathrm{~W}$. The system was designed to operate in blowdown mode (i.e. no regulators were used). A description of the system components follows.

In a flight qualified system, the electrolyzer used would be a zero gravity compatible water vapor feed electrolyzer. The electrolysis unit used in the current experiments, however, was not a flight-type unit, but was a commercial, percolating, cathode gravity liquid feed electrolyzer provided by Hamilton Standard. This unit consisted of a $5-\mathrm{cm}$ diameter, $20-\mathrm{cm}$ high, plexiglass water tower on a $12.5-\mathrm{cm}$ square, $5-\mathrm{cm}$ high base. The electrolysis cell was housed in the base of the unit and was a $45.2-\mathrm{cm}^{2}$, platinized Nafion 117 membrane with polysulfone cell frames. The unit was designed to operate at pressures as high as $1 \mathrm{MPa}$. With the water tower filled up to $15 \mathrm{~cm}$, the total impulse of this system was estimated to be $1000 \mathrm{~N}-\mathrm{s}$ if an Isp of $330 \mathrm{~s}$ is assumed.

Hydrogen, generated inside the electrolysis cell percolated to the top of the tower. A compression fitting installed in the tower wall connected to a 3.18-mm diameter propellant line, which supplied hydrogen to a 300 -cc storage tank, rated for $20 \mathrm{MPa}$. Oxygen generated inside the electrolysis cell accumulated inside the base. Another fitting in the side of the base connected to a 3.18-mm diameter propellant line, supplying oxygen to a 150 -cc storage tank. The tanks were designed to assure nearly equal pressures based on the decomposition.

Solenoid valves installed between the electrolysis unit and the storage tanks were opened during the electrolysis cycle and then closed during thruster firing. The valve closing prevented water from being drawn from the electrolysis tower into the propellant lines by sudden depressurization following ignition. This valve would be eliminated in a true flight design by the use of a zero gravity compatible water vapor feed electrolyzer. Nitrogen purge lines between the tanks and the electrolysis unit allowed the propellants to be purged, exhausting through the rocket nozzle. This feature was only required in ground testing.

Sonic venturis installed inside the propellant lines downstream of the storage tanks fixed the propellant mass flow rates to the thruster. The venturis were designed for specific mass flow rates at inlet pressures of $0.68 \mathrm{MPa}$ to achieve a stochiometric mixture ratio of eight. However, the venturis were calibrated over a range of inlet pressures. The mass flow rates, and thus the chamber pressure, decreased during a blowdown test, as the inlet pressures vary from 1.0 to 0.5 $\mathrm{MPa}$. Calibration data assured that the venturis were choked at all points during blowdown tests for these operating conditions.

Opening of thruster valves, installed downstream of the venturis, caused the venturis to choke, controlling hydrogen and oxygen mass flows to the injector. The injector available for these tests was optimized for a $20-\mathrm{N}$ thruster. As a result, the injector did not provide optimum performance for the current tests, but was good enough for the purpose of this study. The oxygen was injected into a center annulus, where it was excited by a spark ignition system. Six 
small slots on the back of a hydrogen splitter ring provided radial injection of the "igniter hydrogen", while six elements canted inward provided hydrogen injection further downstream. No film cooling was employed. A 5-cm long water-cooled adapter, with a stainless steel boundary layer trip ring, provided additional mixing and was used to mount the chamber to the injector.

Two chambers were tested with the injector. A copper heat-sink chamber was used for checkout of the system, and an Ir/Re chamber was then installed for the majority of testing. The $\mathrm{Ir} / \mathrm{Re}$ chamber, designed for $1-\mathrm{N}$ thrust, consisted of a 8.98-mm diameter chamber and a $2.41-\mathrm{mm}$ diameter throat. The nozzle expansion ratio was 23.3. It had previously undergone life testing and had an accumulated test time of 11.5 hours at a mixture ratio of 5 . The copper chamber had a similar diameter chamber, a $2.43 \mathrm{~mm}$ diameter throat, but a slightly shorter chamber and different converging section.

Thermocouples and pressure transducers at selected locations near the electrolysis unit, the storage tanks, and the thruster, were used to monitor temperature and pressure conditions. Particle filters downstream of the storage tanks removed particles larger than 15 micron to protect valve seats and injector ports. Relief valves rated at $1.0 \mathrm{MPa}$ near the electrolysis unit protected the unit from over pressurization in the case of component malfunction.

\section{Experimental Approach}

The breadboard system was installed and tested inside the high altitude simulation test facility described in Reference 20 . Figure 5 is a photograph of the test configuration. Ambient pressure in the altitude chamber during the test was maintained at approximately $1 \mathrm{kPa}$ using a two-stage ejector. Key data were obtained during the testing of the breadboard propulsion system, both during the propellant generation as well as during the hot-fire test with the thruster.

Key parameters, measured and recorded during the electrolysis fill cycle, were tank pressures and temperatures, electrolysis pressure and temperature, ambient pressure and temperature, and electrolysis current and voltage. The last two variables were determined by the available power. Parameters recorded during hot-fire tests were the pressures and wall temperatures in the combustion chamber, the pressure drop in the tanks in $0.1 \mathrm{~s}$ increments, venturi inlet pressures and temperatures, and ambient pressure and temperature. All data were recorded with a standalone data acquisition system and stored in a personal computer.

In addition to the measured parameters, some additional quantities were calculated. Propellant flow rates could be calculated from the venturi inlet pressures, temperature, and calibration. Both the theoretical and experimental characteristic velocity $\mathrm{C}^{*}$, which is a measure of combustion efficiency, could be determined with standard methods and using the CEC (chemical equilibrium code) ${ }^{21}$ for the given propellant mixture ratio. The $\mathrm{C}^{*}$ efficiency, defined as the ratio of experimental versus theoretical characteristic velocity, was also determined.

In preparation for a series of tests, all air from the electrolysis unit, storage tanks, and propellant lines was evacuated by means of opening the valves to the high altitude environment. After propellant system evacuation, the thruster valves were closed, the supply valves opened, and power was supplied to the electrolysis unit. Hydrogen and oxygen were generated and the storage tanks were filled to a predetermined pressure of around $1 \mathrm{MPa}$. Different power levels were applied at a number of electrolysis cycles in order to establish conversion efficiency variations for varying propellant generation rates. The duration of the propellant fill was between twenty minutes and several hours, depending on the power level. Data were taken at five minute intervals.

A rocket firing followed each tank fill. Thrustervalve opening and spark ignition initiated combustion. The lead time between the spark ignition and the thruster valves opening was preset. For most of the tests reported in this paper, spark ignition and thruster valve opening occurred simultaneously. Combustion chamber pressures decreased during a typical blowdown test from 190 to $138 \mathrm{kPa}$. This range was selected as it bounds the design point of the chamber $(170 \mathrm{kPa})$. A typical test duration was 3-4 s, which was limited by the volume of the tanks and the maximum pressure allowed with the present electrolysis system. Hot-fire tests were terminated after the chamber pressure dropped below a pre-set value, which was selected to provide an acceptable combustion efficiency during this blowdown test. During hotfire tests, data were taken at $100 \mathrm{~ms}$ intervals.

Test conditions varied during a sequence of hotfire tests as the result of changing system conditions. The volume occupied by hydrogen 
consisted of the storage tank, propellant line and head space inside the water tower of the electrolysis unit. The volume occupied by the oxygen consisted of the storage tank and the propellant lines. During the initial tank fill, from high altitude ambient up to $1 \mathrm{MPa}$, the pressure inside the hydrogen tank increased more slowly than inside the oxygen tanks due to the additional head space. The pressure in both tanks remained steady after closing the supply valves. This caused the mixture ratio of the first hot-fire in a test sequence to be oxygen rich $(\mathrm{O} / \mathrm{F} \sim 9.2)$.

Because high pressure hydrogen was trapped inside the electrolysis tower, the hydrogen tank experienced an increase in pressure each time the supply valve opened. As a result, the pressure inside the hydrogen tanks was higher than in the oxygen tanks during subsequent tests, causing a slightly hydrogen rich mixture ratio ( $\mathrm{O} / \mathrm{F} \sim 7.6$ ). About 8 test sequences were required to reach marginal equilibrium conditions, because the space inside the water tower changed as a result of water consumption. Even though conditions changed slightly during continuing testing, chamber pressure, $\mathrm{O} / \mathrm{F}$ ratios, and characteristic velocities did not change noticeably. Throughout the full course of testing, the thruster performed well.

\section{Electrolysis System Performance}

Key parameters during an electrolysis tank fill were the supplied voltage, the current through the cells, the pressure build-up inside the oxygen and hydrogen storage tanks, the electrolysis unit temperature, and the rate of propellant generation (measured in total fill time to an oxygen tank pressure of $1 \mathrm{MPa}$ ). The electrolysis voltage provides a measure of cell conversion efficiency This efficiency decreases with increasing cell current and electrolysis pressure, and decreases slightly with cell temperature. Cell voltage ranged from $1.47 \mathrm{~V}$ at $1 \mathrm{kPa}$ and $1 \mathrm{~A}$ to $1.81 \mathrm{~V}$ at $1 \mathrm{MPa}$ and $10 \mathrm{~A}$. Electrolysis tests were performed at a variety of different cell currents, from 2 to $10 \mathrm{~A}$. The current was kept at a constant value during each test. The increasing pressure inside the electrolysis unit during each test caused the cell voltage to gradually increase, requiring a slightly higher power for conversion than at lower operating pressures. The constant current assured a constant propellant generation rate.

Fig. 6a, b, and c show the electrolysis power required to maintain constant propellant generation rate with increasing pressure, for oxygen generation rates of $7.5,18.7$, and 37.5 sccm, respectively, which correspond to 2,5 , and $10 \mathrm{~A}$ cell current. These cell currents translate to approximately 3,8 and $16 \mathrm{~W}$ available power, typical for small spacecraft. The horizontal axis displays the pressure in the oxygen storage volume. The range displayed is from 0.6 to 1.0 $\mathrm{MPa}$, approximately the pressure range when cycling between electrolysis charge and hot-fire discharge. The vertical axis shows the power required. Fig. 6 shows that the required power increases, as expected, with increasing storage pressure, and that this increase is larger for higher generation rates. These experiments showed that the electrolysis conversion efficiency decreased gradually with increasing pressure, as expected by theory, due to the energy required for gas compression and to the internal hardware configuration. This pushes design tradeoffs of an electrolysis propulsion system toward lower maximum electrolysis pressure in order to maximize efficiency. The stepwise increase in Fig. $6 a$ is due to the characteristics of the data acquisition equipment.

Increasing the input power leads to an increase in propellant generation rate. Fig. 7a shows the average power required as a function of oxygen generation rate. The vertical axis of this figure is taken as the average power required between 0.6 and 1.0 MPa oxygen storage pressure. The figure shows an approximately linear relationship between input power and generation rate, with a value of $0.46 \mathrm{~W} /(\mathrm{sccm}$ oxygen $)$.

As was shown in Fig. 6, a difference exists between power required at $0.6 \mathrm{MPa}$, and 1.0 $\mathrm{MPa}$. This is displayed in Fig. 7b, which shows that the absolute difference between power levels required at $0.6 \mathrm{MPa}$ and $1.0 \mathrm{MPa}$ increases with increasing propellant generation rates. The average electrolyzer efficiency is defined as the minimum power theoretically required for water electrolysis divided by the actual power used. The remaining power is rejected as heat. Typical efficiency values for electrolysis are between 85 and $90 \%$.

\section{Rocket Testing}

As noted previously, initial rocket test sequences were executed with a copper heat-sink chamber. Temperature, pressure, and propellant mixture ratio data were obtained to verify that test conditions remained within their expected ranges. Typical copper combustion chamber pressures are shown in Fig. 8 as a function of time. At the initiation of testing, the thruster valves opened, the spark igniter was tumed on, and the chamber pressure increased as the result 
of gas inflow. The first pressure increase was detected after $100 \mathrm{~ms}$. The likely cause of this delay in measured pressure rise was slow dynamics in the pressure sensing port inside the injector. During the next $100 \mathrm{~ms}$, the pressure increased to approximately $69 \mathrm{kPa}$. A slight (100-150 ms) hesitation was detected before ignition occurred. The pressure rise through ignition was not smooth. Such a "step" was undesirable for performance reasons. A similar step was found in testing at Marquardt with a $0.45 \mathrm{~N}$ thruster. ${ }^{2}$ Further development under that program succeeded in eliminating this undesirable phenomenon by a redesign of the ignitor. The step was present during both the copper chamber tests, and the Ir/Re thruster tests, suggesting that it was caused by the injector/igniter design which was not optimized for these laboratory experiments.

Ignition occurred at approximately $250 \mathrm{~ms}$ after test initiation, after which the pressure increased sharply until hot test equilibrium conditions were reached. Subsequently, the chamber pressure decreased as the propellant supply pressures decrease and less mass flowed into the chamber.

Fig. 9a show typical combustion chamber pressures during the $\mathrm{Ir} / \mathrm{Re}$ thruster tests. All of the hot-fire tests show the same step in combustion chamber pressure increase that was shown in Fig. 8. Again this was attributed to the fact that the ignition was not optimized. Such a step should not present an issue in a flight type system. As a result of slightly different chamber dimensions in the Ir/Re thruster, as compared to the copper chamber, the cold gas pressure buildup reached a higher pre-ignition equilibrium level, $\sim 78$ vs. $\sim 68 \mathrm{kPa}$; and at a later stage, $\sim 400$ ms vs. $\sim 200 \mathrm{~ms}$. Ignition always occurred, with delays varying from 50 to $150 \mathrm{~ms}$. The ignition delay is shown in Fig. 9a. Pressure rise after ignition was slow. A maximum pressure between $173 \mathrm{kPa}$ and $190 \mathrm{kPa}$, depending on mixture ratio, was reached $\sim 1 \mathrm{~s}$ after test initiation. After that, the chamber pressure gradually dropped as the result of decreasing propellant supply pressures and thus mass flow rates. The hot-fire, low-pressure abort limit for this specific series of tests was set to $136 \mathrm{kPa}$, which ended the tests. The abort limit was selected to provide an acceptable combustion efficiency during blowdown tests. This was corroborated by alternate test series done with abort limits of 68 $\mathrm{kPa}$ and $34 \mathrm{kPa}$.

Fig. $9 \mathrm{~b}$ shows the propellant mixture ratio (O/F ratio) during the series of tests. As previously described, the first hot-fire test experienced a high $\mathrm{O} / \mathrm{F}$ ratio of 9.3 due to the higher oxygen tank pressure. This caused the oxygen mass flow rate to be greater than stoichiometric. Therefore, during the test, the $\mathrm{O} / \mathrm{F}$ ratio dropped slightly. Subsequent tests showed lower $\mathrm{O} / \mathrm{F}$ values, with an approximate equilibrium reached at an $\mathrm{O} / \mathrm{F}$ of 7.5. The variation in mixture ratio was caused by the particular geometry used in the bench test, where the hydrogen storage volume was more than twice the oxygen storage volume. A configuration designed for optimum performance is not expected to show this large variation, but is expected to operate at a nearly constant $\mathrm{O} / \mathrm{F}$ of -8 .

Fig. 9c shows the $\mathrm{C}^{*}$ efficiency. It shows that the maximum $C^{*}$ efficiency was obtained after approximately $1.2 \mathrm{~s}$. This indicated that a significant fraction of the propellant mass was expelled before optimum conditions were reached. The maximum $C^{*}$ efficiency was approximately 0.79 . This level of performance was expected as the result of the non-optimized design of injector, water-cooled adapter section, and chamber.

The thruster was designed for optimum performance at $170 \mathrm{kPa}$ chamber pressure. This was reached at approximately $1.5 \mathrm{~s}$, which is indeed where the maximum combustion efficiency is obtained. After this maximum, the combustion efficiency decreases as the chamber pressure decreases and the conditions move away from optimum. External chamber wall temperatures did not exceed $1800^{\circ} \mathrm{F}$.

\section{Summary}

Electrolysis propulsion has been recognized as an attractive option for satellite and spacecraft over the decades, but has not yet been used for in-space missions. Recent advances in water vapor feed electrolysis, propellant tankage, thruster chamber materials, and fuel cell technology warrants renewed consideration for the electrolysis propulsion option. An electrolysis propulsion system would generate $\mathrm{GH}_{2} / \mathrm{GO}_{2}$ propellants, without the need for a pressurization system, pumps, or compressors. The gaseous propellant tanks can be sized for the largest burn required for the mission, with the bulk of the propellant stored as water until needed.

Electrolysis propulsion would provide higher performance than the established chemical propulsion options and at the same thrust levels. 
Furthermore, the water propellant greatly simplifies ground loading and servicing requirements and eliminates many of the handling compatibility concerns of toxic earth storable propellants. The real attractiveness of electrolysis propulsion might be the ability to serve in the dual role of propulsion and power generation. The tankage in this unitized system can also provide some, if not most of the structure required by spacecraft that must function as a stiff instrument platform. A unitized electrolysis/fuel cell unit would provide high performance propellants for propulsion and generate power. This might be a critical function for deep planetary missions, where solar power will become more scarce as the mission proceeds and where load leveling can be an important asset.

The state of the technology for the components of a flight-type system were discussed and a propulsion breadboard system was assembled. A series of cycles with alternate propellant generation by means of water electrolysis and subsequent hot-fire thruster tests was demonstrated on this breadboard system. Hydrogen and oxygen produced during the electrolysis process were stored inside small, high pressure tanks. The thruster used was a high temperature, oxidation resistant, rheniumiridium, $1 \mathrm{~N}$ chamber, attached to a workhorse injector by means of a water-cooled adapter section.

Oxygen to hydrogen mixture ratios varied between 7.5 and 9.5 , with highest $C^{*}$ efficiency at the lowest mixture ratio as expected. The proof-of-concept test bed that was not designed and optimized for performance had a maximum $\mathrm{C}^{*}$ efficiency of $79 \%$. Optimization of thruster design will generate significantly better performance than those of state of the art bipropellents.

The tests described in this paper showed the fundamental feasibility of the unitized propulsion and power concept. URFC cycle tests and electrolysis propulsion tests demonstrated that the system worked as anticipated. A fully functional unitized propulsion and power system featuring a water vapor feed URFC is needed to demonstrate the great advancements that can be made using this technology.

\section{References}

'Wilson, A., Jane's Space Directory, $12^{\text {th }} E d$. 1996-1997, Jane's Information Group Ltd., Sentinel House, Surrey, England, UK, 1994, pp.334.

${ }^{2}$ Myers, R.M., Oleson, S.R., Curran, F.M., and Schneider, S.J.,"Chemical and Electrical Propulsion Options for Small Satellites," Proceedings of the $8^{\text {th }}$ AIAA Utah State University Conference on Small Satellites, Aug. 29 - Sept. 1, 1994.

${ }^{3}$ Sutherland, G. S., and Maes, M. E.: “A Review of Microrocket Technology: $10^{-6}$ to 1 lbf Thrust," J. Spacecraft and Rockets, Vol. 3, No. 8, August 1966.

${ }^{4}$ Newman, D. P., "Water electrolysis reaction control system," $7^{\text {th }}$ Liquid Propulsion Symposium, Chemical Propulsion Information Agency Publ. 72, pp105-114, Oct. 1965.

${ }^{5}$ Stechman, R.C., Campbell, J.G. "Water Electrolysis Satellite Propulsion System," The Marquardt Company, Technical Report AFRPLTR-72-132, January, 1973.

${ }^{6}$ Mitlitsky, F., Myers, B., and Weisberg, A.H., "Lightweight pressure vessels and unitized regenerative fuel cells, " 1996 Fuel Cell Seminar, November 17-20, 1996, Orlando, FL; UCRL-JC125220 and UCRL-MI-125220.

${ }^{7}$ McElroy, J.F., "Unitized regenerative fuel cell storage system for aircraft and orbital applications," UTC Hamilton Standard div., Rept. BD94-02, March 1994.

${ }^{8}$ Mitlitsky, F., de Groot, W.A., Butler, L., and McElroy, J.F., "Integrated Modular Propulsion and Regenerative Electro-Energy Storage System (IMPRESS) for Small Satellites," 10th annual AIAA/USU Conference on Small Satellites, September 16-19, 1996, Logan, UT 84322 .

${ }^{9}$ Fanciullo, T.J., and Judd, D.C., "Long Life Reaction Control System Design," AIAA Aerospace Design Conference, AIAA Paper 920964, Irvine, CA, February 16-19, 1993. 
${ }^{10}$ Campbell, J.G., and Stechman, R.C., "System Testing, Water Electrolysis Propulsion," AFRPL-TR-74-72, The Marquardt Co., Nov. 1974.

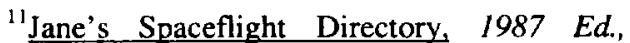
Jane's Publ. Co. Lid, London, New York, pp. 65 67, 1987.

${ }^{12}$ MOOG Space Products Division, Miniature Latching Solenoid Valve Data Sheets, 1996

${ }^{13}$ Reed, B. D. and Schneider, S. J.: "Hydrogen/Oxygen Auxiliary Propulsion Technology," AIAA Paper 91-3440, NASA TM105249, September 1991.

${ }^{14}$ Rollbuhler, R. J.: "Experimental Performance of a Water Electrolysis Rocket," NASA TM X-1737, 1968.

${ }^{15}$ Richter, G. P. and Price, H. G., "Proven, Long-Life Hydrogen/Oxygen Thrust Chambers for Space Station Propulsion," JANNAF Propulsion Meeting, New Orleans, Aug. 1986. See also NASA TM-88822.

${ }^{16}$ Iacabucci, R. S., et al.: "Space Station Technology Summary," 1989 JANNAF Propulsion Meeting, Vol. I, CPIA Publ. 515, 1989.

${ }^{17}$ Schoenman, L.: "4000 of for Low Thrust Rocket Engines," AIAA Paper 93-2406, June 1993.

${ }^{18}$ Reed, B. D., "Long-Life Testing of OxideCoated Iridium/Rhenium Rockets," $31^{\text {st }}$ Joint Propulsion Conference, AIAA Paper 95-2401, June, 1995.

${ }^{19}$ Reed, B.D. and Schneider, S.J., "Hydrogen/Oxygen Auxiliary Propulsion Technology," NASA TM-105249, AIAA Paper 91-3440, presented at the Conference on Advanced Space Exploration Initiative Technologies, Cleveland, $\mathrm{OH}$, September 4-6, 1991.
${ }^{20}$ Arrington, L.A. and Schneider, S.J., "Low Thrust Rocket Test Facility," AIAA Paper 902503, Orlando, FL, 1990.

${ }^{21}$ Gordon, S., and McBride, B., "Computer Program for Calculation of Complex Chemical Equilibrium Composition, Rocket Performance, Incident and Reflected Shocks, and ChapmanJouget Detonations," NASA SP-273, March 1976.

Table I: Demonstrated Technology Readiness Levels.

\begin{tabular}{|l|l|l|}
\hline Element & $\begin{array}{l}\text { NASA } \\
\text { TRL }\end{array}$ & Comments \\
\hline SPE Fuel Cell & Level 9 & Gemini \& Biosat. \\
\hline $\begin{array}{l}\text { SPE } \\
\text { Electrolyzer }\end{array}$ & Level 6 & Air Force Program \\
\hline SPE URFC & Level 4 & $\begin{array}{l}\text { 2010 Laboratory } \\
\text { Cycles } \\
\text { Demonstrated } \\
\text { @ LLNL }\end{array}$ \\
\hline $\begin{array}{l}\text { Gas Dryers } \\
\text { Thrusters } \\
\text { - Valves } \\
\text { - Combustion } \\
\text { Chamber } \\
\text { - Ignition }\end{array}$ & Level 6 & JSC Program \\
\hline $\begin{array}{l}\text { Graphite } \\
\text { Bladder } \\
\text { Tankage }\end{array}$ & Level 4 & $\begin{array}{l}\text { NASA and DOD } \\
\text { Programs }\end{array}$ \\
\hline
\end{tabular}




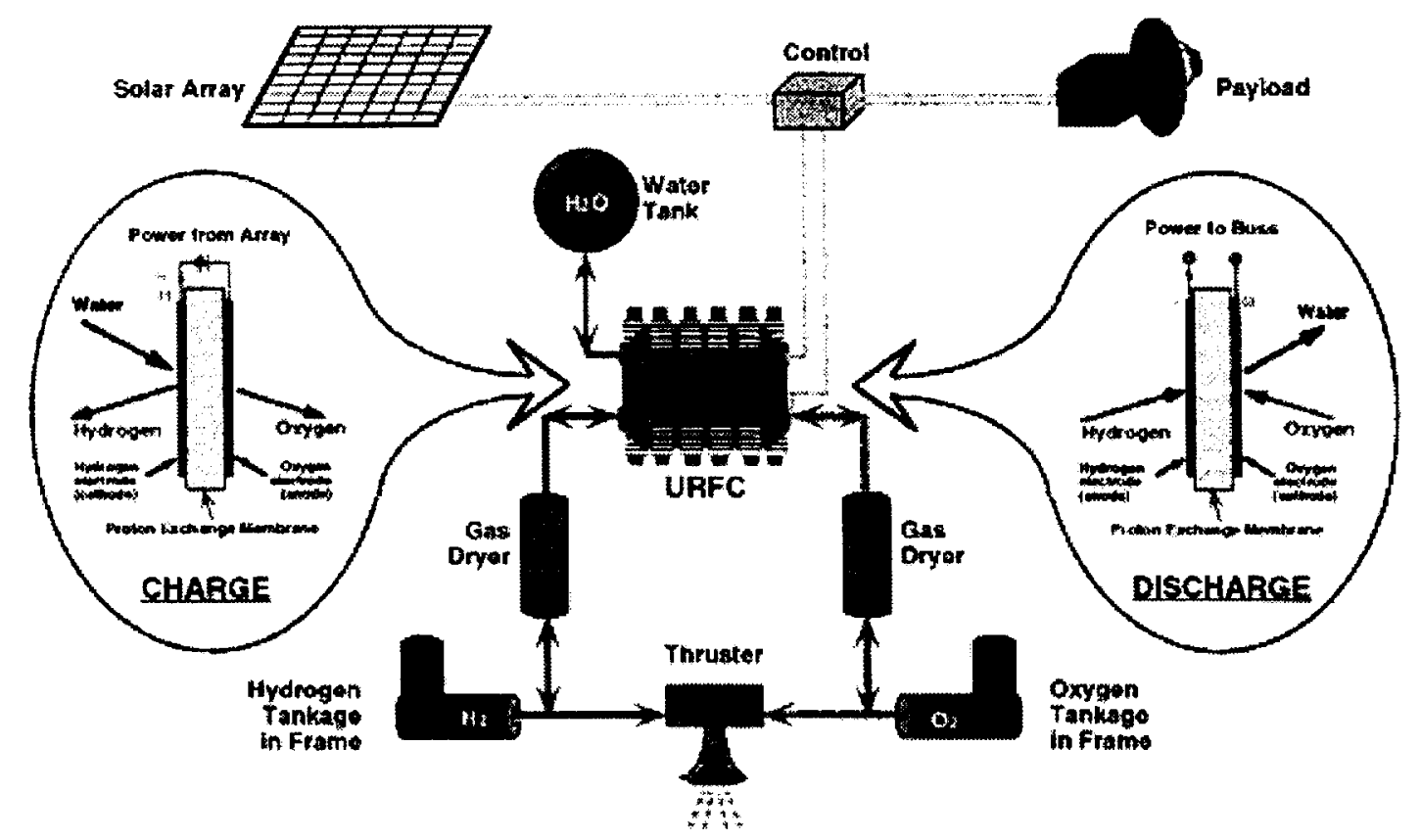

Figure 1: Integrated Modular Propulsion and Regenerative Electro-Energy Storage System (IMPRESS)

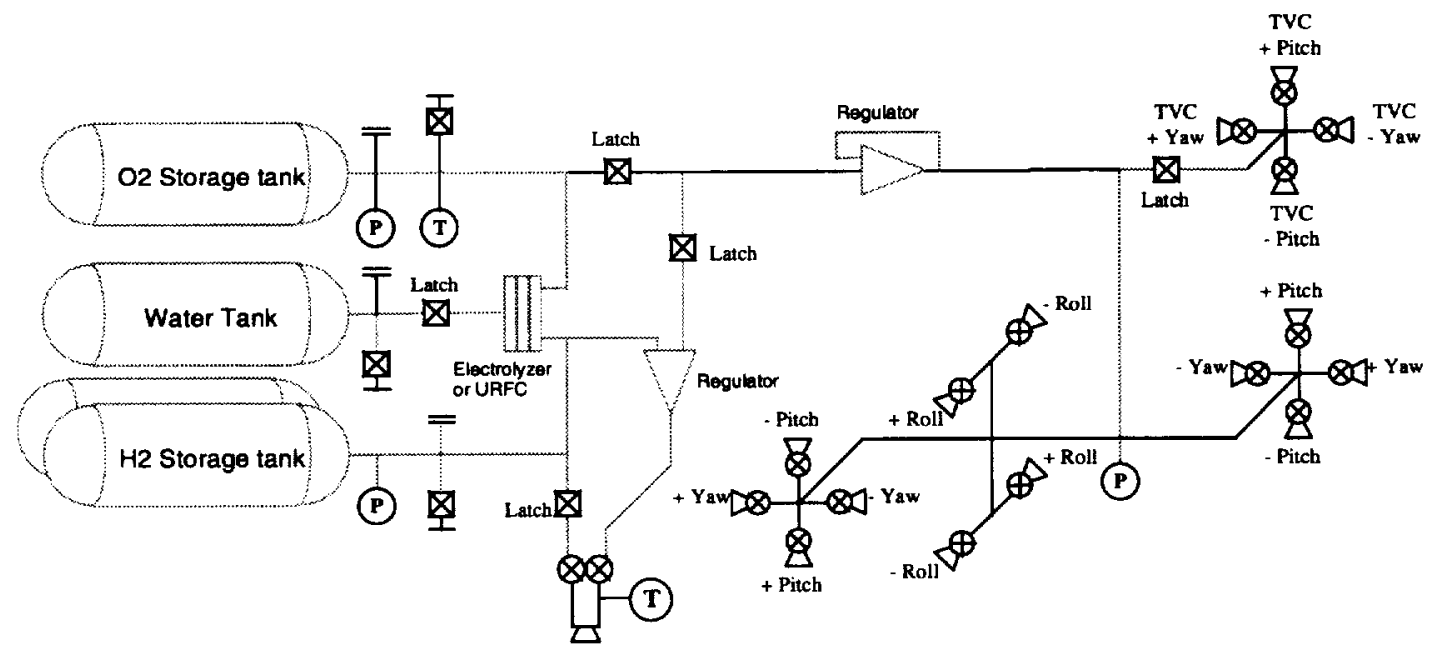

Figure 2: Schematic of Dual-Mode Electrolysis Propulsion System 


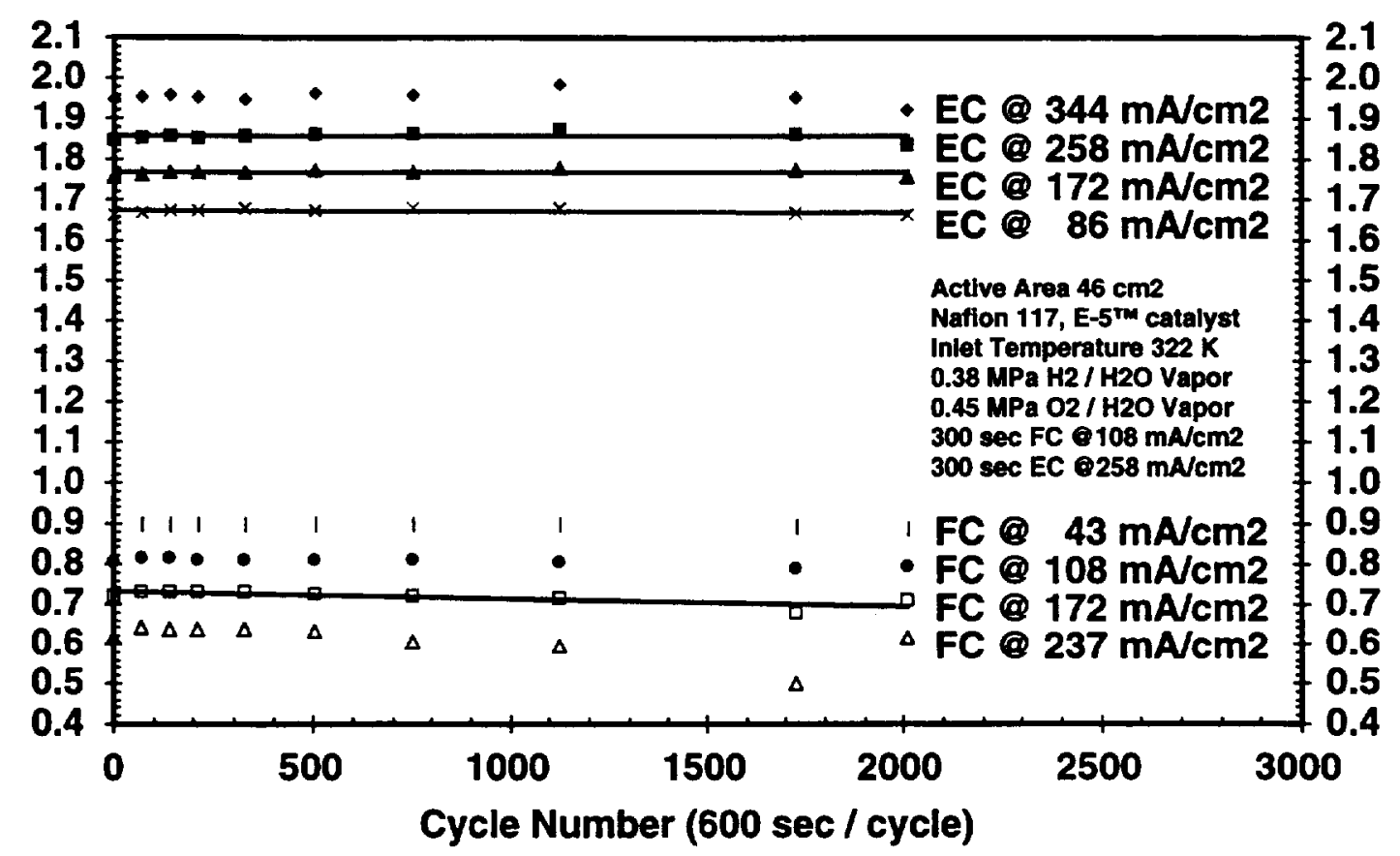

Figure 3: Measured Performance as a Function of Cycle Number for a Single Cell URFC

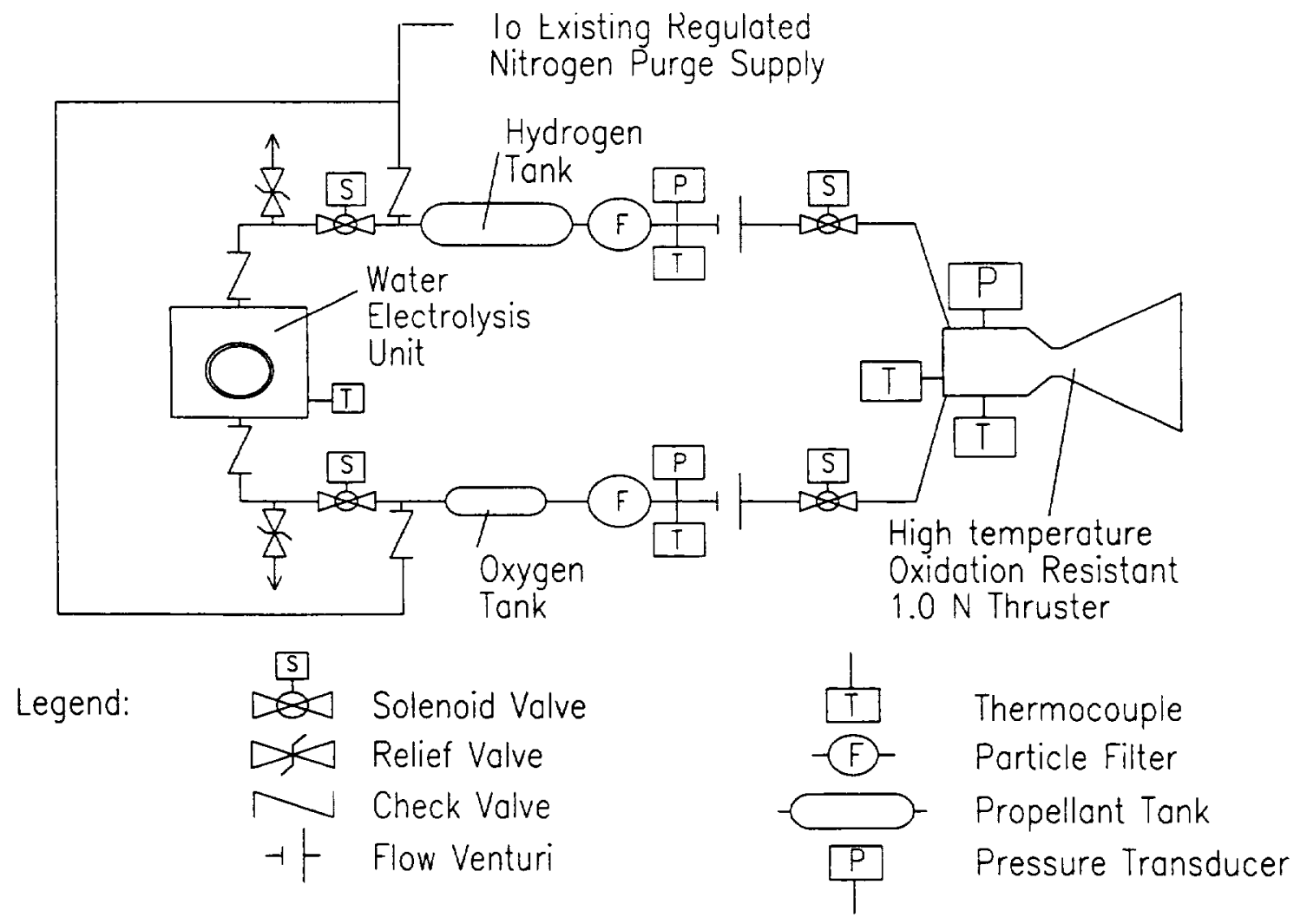

Figure 4: Water Electrolysis Propulsion System Breadboard Schematic 


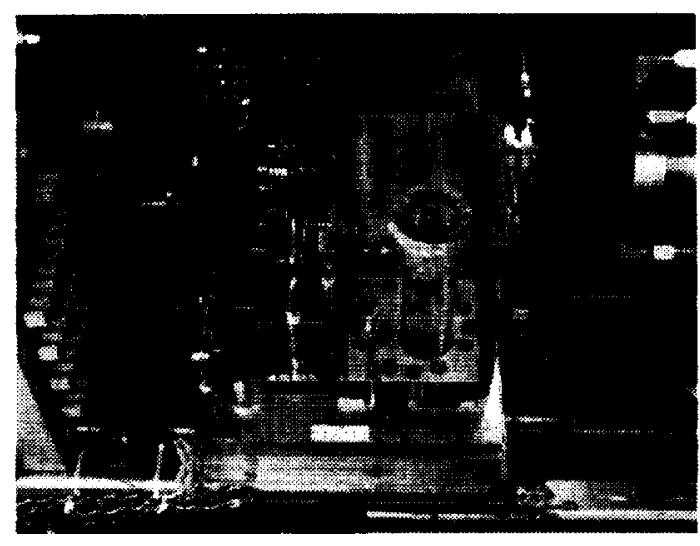

Figure 5: Photograph of Electrolysis Propulsion Breadboard Installed Inside High Altitude Chamber

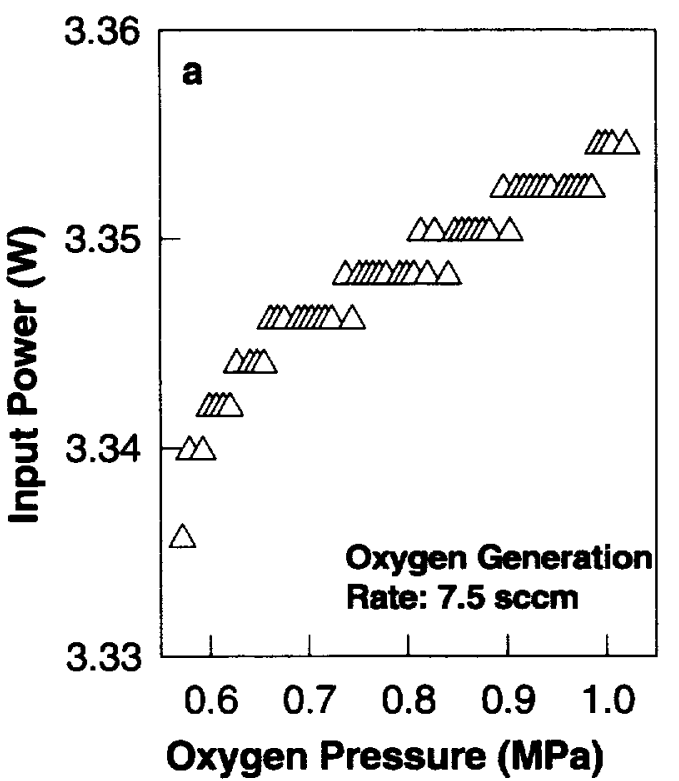

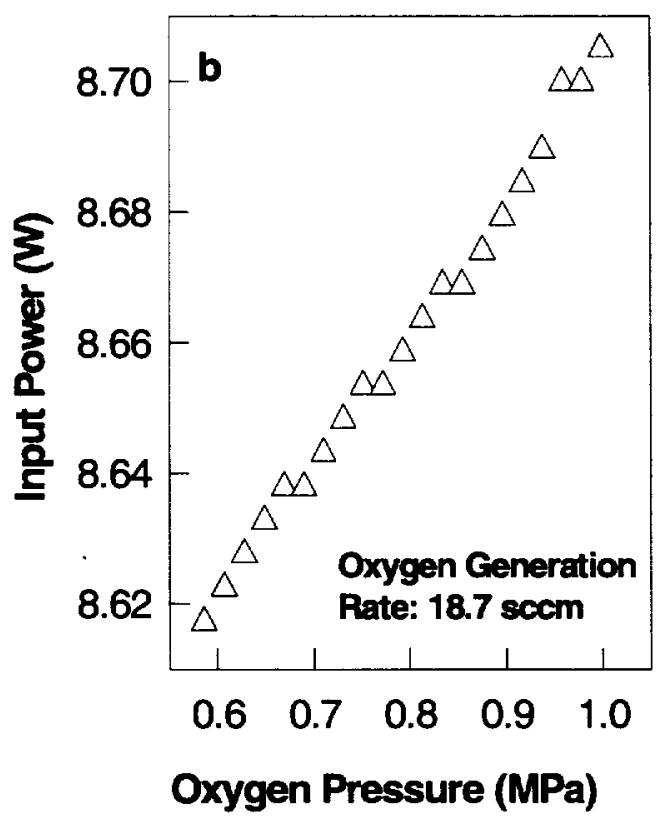

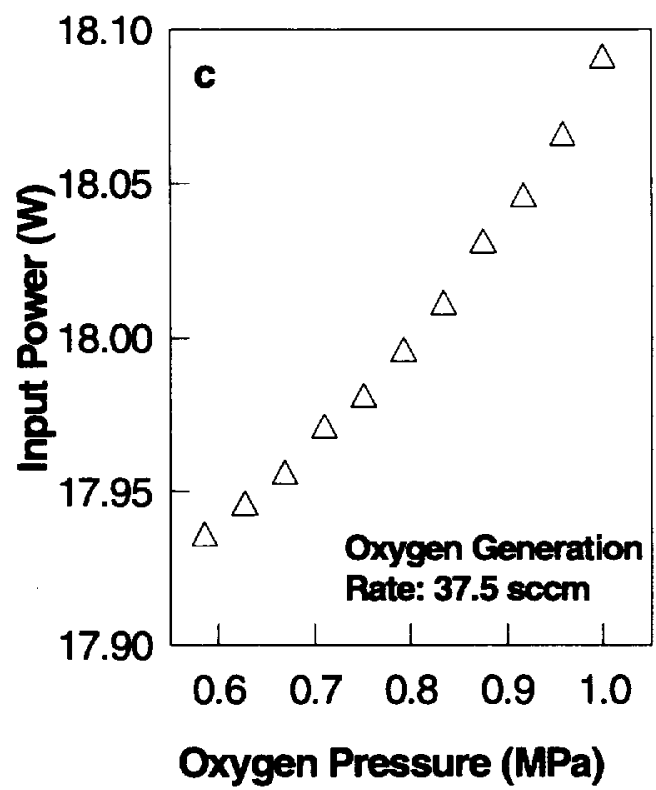

Figure 6: Average Electric Power Required to Maintain Constant Propellant Generation Rate at Increasing Pressures. $\mathrm{O}_{2}$ Generation Rates:

a) $7.5 \mathrm{sccm}$; b) $18.7 \mathrm{sccm}$; c) $37.5 \mathrm{sccm}$. 

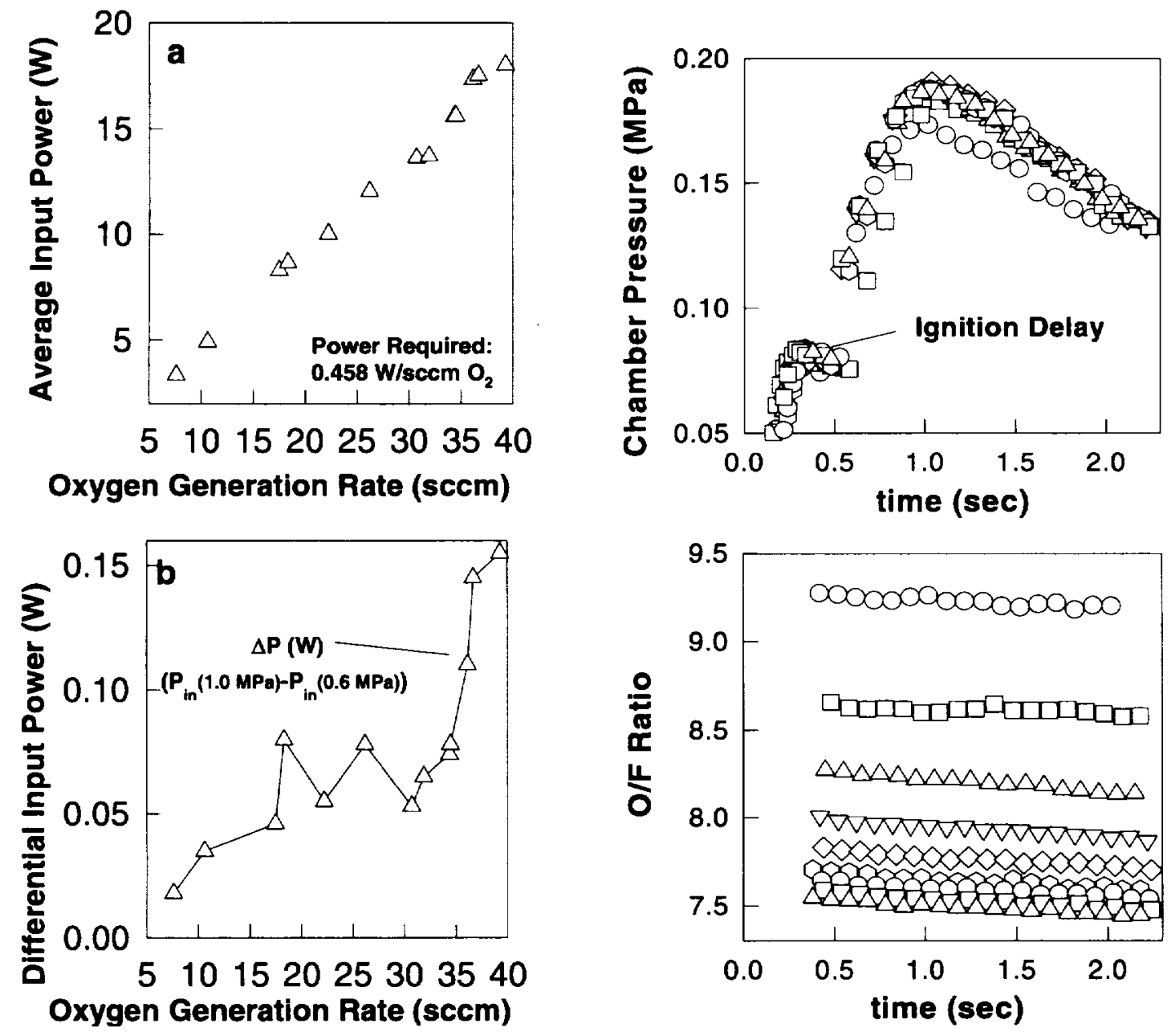

Figure 7: Electrolysis Power Characteristics as a Function of Propellant Generation Rate: a) Average Power Required; b) Difference in Power Required at 0.6 and $1.0 \mathrm{MPa}$ Pressure.
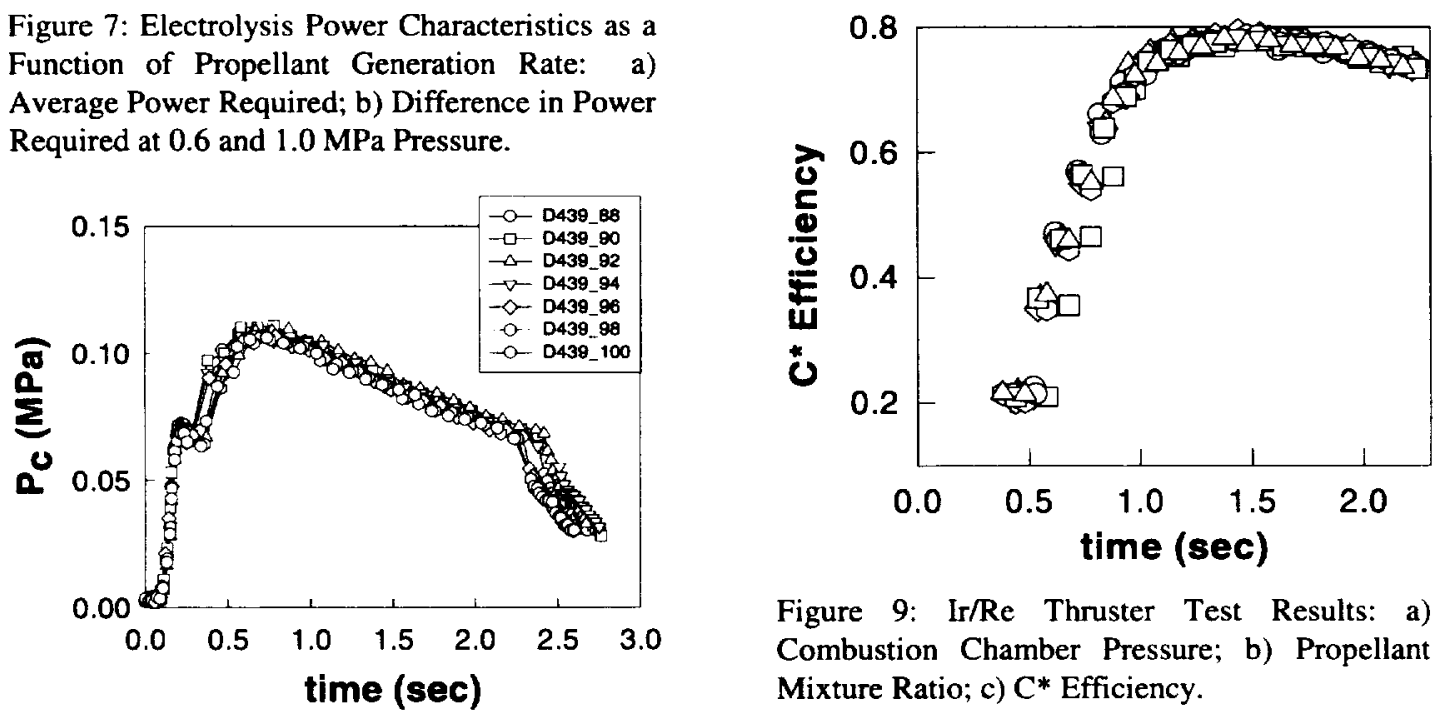

Figure 9: Ir/Re Thruster Test Results: a) Combustion Chamber Pressure; b) Propellant Mixture Ratio; c) C* Efficiency.

Figure 8: Copper Combustion Chamber Pressures for a Series of Hot-Fire Tests. 


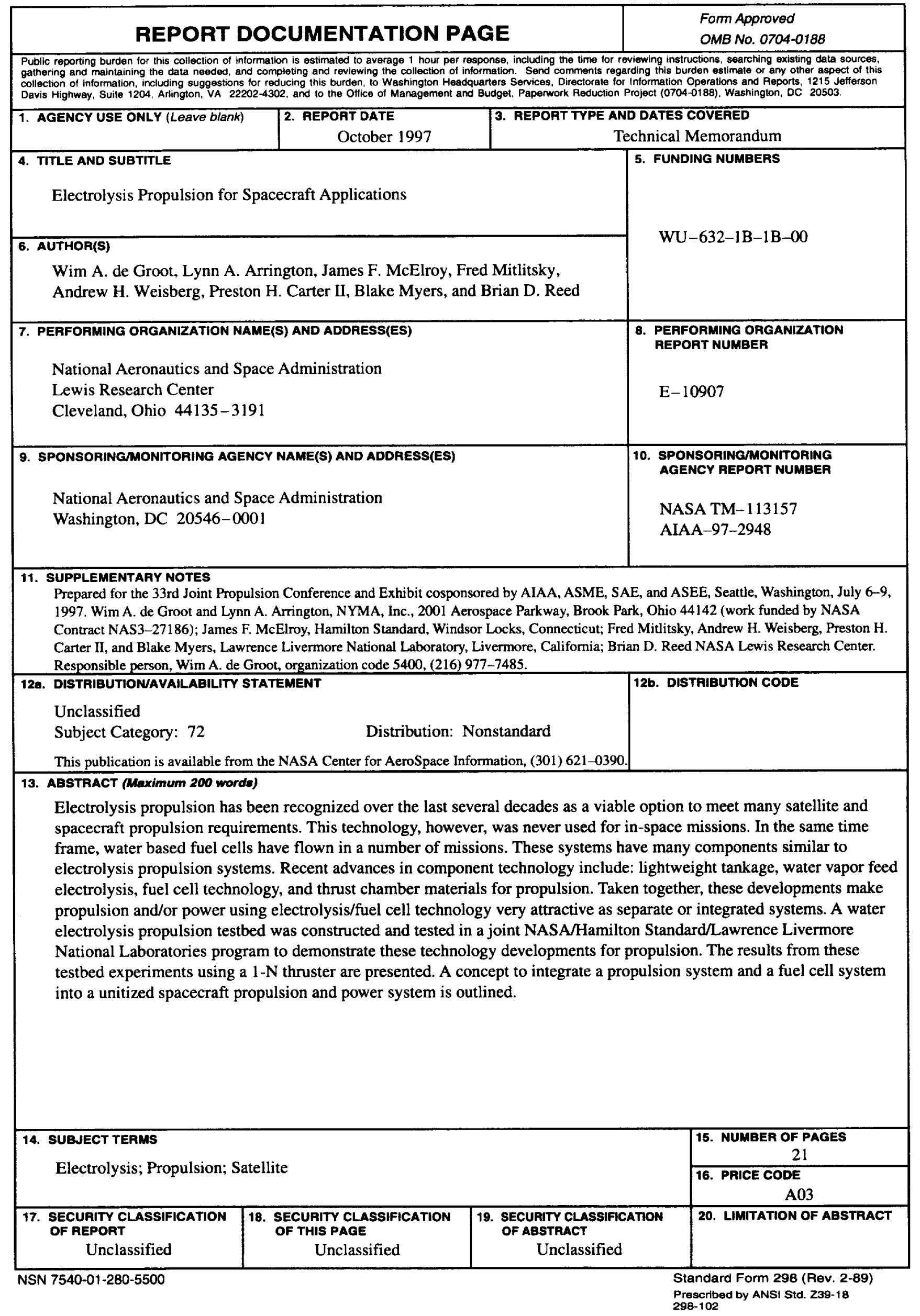

